\title{
NEW BRECHTIAN IMPULSES IN CONTEMPORARY FINNISH THEATRE: A CASE STUDY OF JUHA JOKELA'S ESITYSTALOUS (2010)
}

\section{NIKLAS FÜLLNER}

\begin{abstract}
At the beginning of the 21st century, Finnish theatre experienced a wave of new, politically engaged drama that came hand in hand with a renewal of aesthetics and dramaturgical strategies. One component of this renewal was a new perspective on Brecht's epic theatre, which was initiated by visits of Finnish theatre directors to theatre performances, for example, by Frank Castorf, in Germany. As a consequence of this, an interweavement of Brechtian aesthetics and Finnish theatre tradition became a trend on Finnish stages. One example of this is Juha Jokela's E sitystalous (Performanœ E conomy), which was premiered at Espoon Kaupunginteatteri in 2010. Here, Jokela uses Brechtian alienation effects to put the audience in the position of a critical observer. However, he does not dissolve the unity of actor and role, but sticks to the Finnish acting tradition, thereby creating his very own aesthetics of a new political theatre.
\end{abstract}

Keywords: Finnish theatre, political theatre, Bertolt Brecht, Frank Castorf, Juha Jokela

\section{THE BOOM OF THE NEW FINNISH DRAMA}

At the beginning of the 21 st century, Finnish theatre experienced a wave of new politically engaged drama. This trend was preceded by the rapid and severe changes that Finnish society had undergone in the 1990s. The collapse of the Soviet Union had led to a serious economic and financial crisis, which turned mainstream political and economic thinking into a more neoliberal direction. Finland had changed into a service society; flexible forms of working, precarious employment relationships, and problems such as long-term unemployment and poverty suddenly appeared on the political agenda. At the same time, the following question emerged: how could the welfare state be maintained in a time of economic instability? The Finnish theatre reacted to the social changes and started to reflect them on stage. Political issues had not been very prominent on Finnish stages since the late 1970s, but now they started to be discussed again. This development went hand in hand with the boom of new Finnish drama that started around the same time and followed a trend which could be observed in several Western European countries simultaneously. ${ }^{1}$ With the beginning of the new century, new Finnish plays started to be more and more strongly represented in the programmes of 
the theatres. Today, premieres of Finnish plays make up on average one fourth of the repertoire, ${ }^{2}$ which is quite a high number compared to Germany, for example, where the share of new plays in the repertoire today is only $10 \% .^{3}$ These new plays much more often and in a more direct way than in the decades before touch current political issues. Thus, the new dramatists are contributing, as Hanna Helavuori puts it, to a repoliticization of the Finnish society. ${ }^{4}$

\section{REDISCOVERING BRECHT}

In their search for ways to reflect and comment on political and societal issues in a critical way, the new dramatists developed different strategies. Interestingly, a number of the playwrights who also often act as directors of their own plays, returned to the methods of Bertolt Brecht's epic theatre. There had already been approaches to Brecht's epic theatre in Finland before, but a deeper and a more critical understanding of his theories was not widespread among theatre makers. The problem was that the theatre makers in the leftist-oriented $60 \mathrm{~s}$ and $70 \mathrm{~s}$ had used Brecht's name as a label for their own political theatre, but did, in fact, only apply a few elements of his theory in their work. As the Finnish Brecht reception was influenced by the official East German Brecht reception of that time, Brecht was often not understood as a critical and dialectical thinker, but as a Marxist who wanted to convey a clear message. After the dogmatic form of theatre that emerged from this approach met with disapproval at the end of the seventies, both political theatre and Brecht were abandoned and forgotten for the following decades as they were regarded as one and the same by many theatre makers and critics. ${ }^{5}$

However, at the turn of the century, when political issues returned to Finnish stages, a trend could be observed among Finnish theatre makers to return to the Brechtian theatre concept. Again this trend was influenced by East German or more precisely East Berlin theatre, which was now freed from the dogmatic GDR readings of Brecht. Several Finnish directors as, for example, Esa Leskinen and Mika Myllyaho, at this time artistic directors of the Ryhmäteatteri, travelled to Berlin in the nineties. Watching contemporary German theatre performances, they noticed the common use of the verfremdungseffekt and recognised it as a possible way to break away from the still prevailing tradition of social realism in Finnish theatre and to develop a new form of political theatre. ${ }^{6}$ In an interview, Finnish playwright and director Mika Myllyaho, today director of the Finnish National Theatre, recounts: "We travelled a lot to Berlin in the nineties. And I was watching a lot at the Volksbühne. The first time was in 1994. In Germany, you still have this Brecht influence. All the rules are still coming from Brecht. And then the people in the audience have to start more to think than to feel. And I thought, we have to know something about that here." ${ }^{17}$

The Volksbühne, especially the productions directed by its artistic director Frank Castorf, were regarded as radical and avant-garde in the 1990s and attracted a large audience. Castorf's idea to put big screens above the stage displaying live video footage, such as close-ups of the faces of the actors, but also places of the stage which were otherwise not visible for the audience, were particularly regarded as innovative and were copied by many other directors all over Europe in the following years and not only in the context of political theatre. While the devices Castorf used were new in the 1990s, his approach to theatre can be traced back to the Brechtian theatre concept as he applies the verfremdungseffekt and other ideas associated with Brechtian epic theatre, such as montage and the use of music, as well as more radical techniques of deconstruction and postmodern structure as advanced by Heiner Müller, ${ }^{8}$ as Steve Earnest puts it.

Mika Myllyaho and Esa Leskinen started to experiment with their own, new Brechtian political approach at Ryhmäteatteri and others, such as Kristian Smeds and Juha Jokela performed similar experiments at other theatres at the same time. As Myllyaho puts it, he wanted to know if Brecht still exists. And it works very well all the time. ${ }^{9}$ Myllyaho was so convinced by the Brechtian approach that, when he became lecturer 


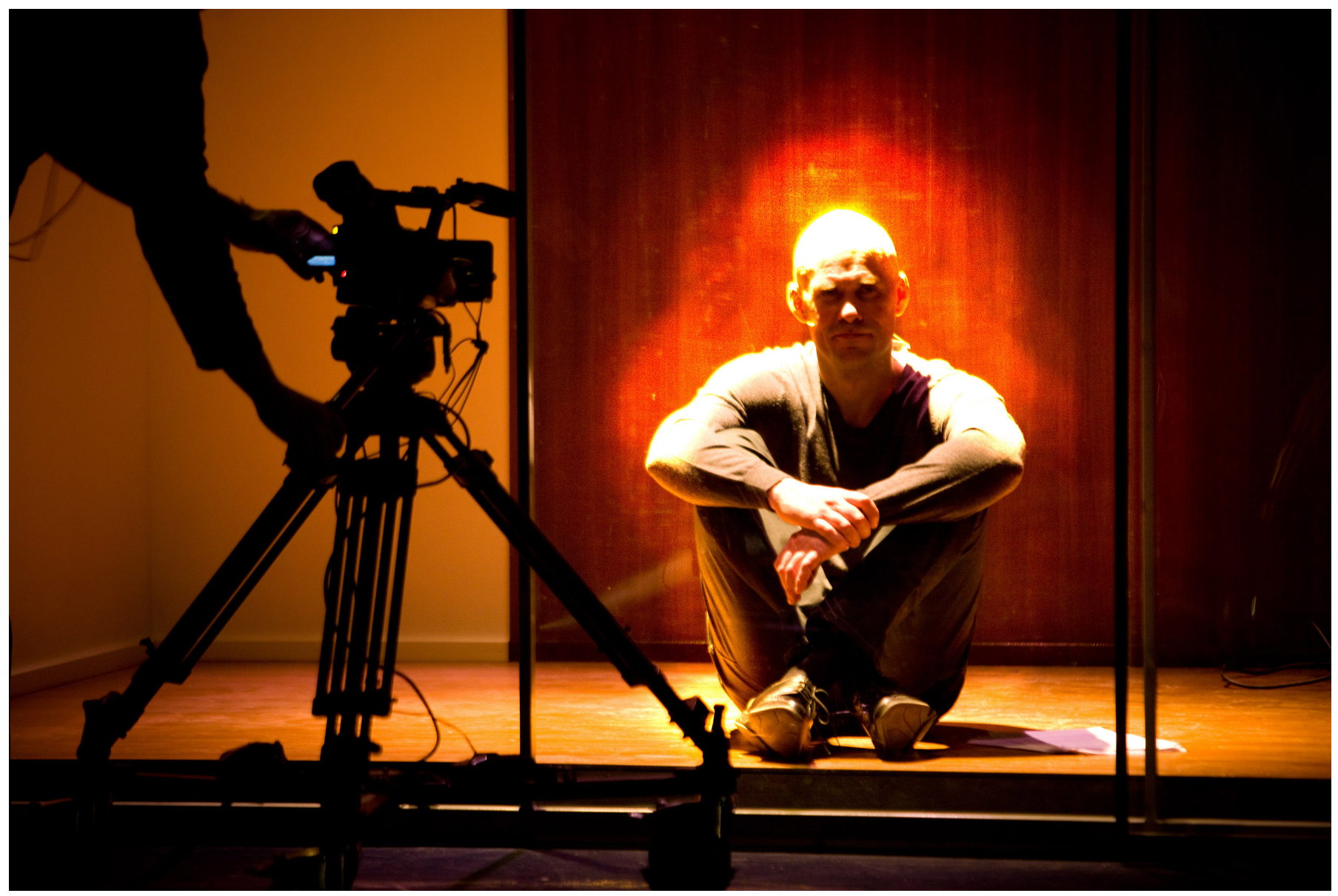

Tommi Korpela in Juha Jokela's E sitystalous (2010) at the E spoo City Theatre. Photo Stefan Bremer.

for directing at the Theatre Academy in Helsinki in 2002, he and his colleagues decided to establish a Brecht course in the curriculum, which became, and still is, obligatory for all students. Teaching Brecht to future Finnish theatre makers, Myllyaho aimed at widening their horizon for a critical theatre that makes the audience think and not merely consume. ${ }^{10}$ In the following years, Brechtian techniques in writing as well as in directing appeared more and more on Finnish stages and can be found especially in the works of the younger generation of graduates of the Academy as, for example, in the plays by Emilia Pöyhönen and Saara Turunen.

\section{A CASE STUDY OF JUHA JOKELA'S ESITYSTALOUS}

To explain the use of Brechtian techniques in todays Finnish theatre I will focus in the following on one example, Juha Jokela's Esitystalous (in English: Performanœ E conomy) and compare it to Castorf's approach. ${ }^{11}$ As the use of Brechtian methods in Finnish theatre today is very diverse, this case study does not claim to represent the contemporary Finnish approach to Brecht in general but aims to describe only one example of a trend that can be observed in Finnish theatre today.

Esitystalous, directed by Juha Jokela at the Espoon Kaupunginteatteri, the City Theatre of Espoo and which had its premiere on 10 February 2010, was a very successful production that was invited to the Tamperen Teatterikesä, the biggest Finnish theatre festival, in 2010 and was followed by the sequel Esitystalous 2 in 2013. Let me first give you a short summary of Jokela's play: The neoliberal business coach, Rami Niittymaa, and the social democrat member of parliament and physician, Jaana Sallinen, are at the centre of the action. While Rami is supporting a marketing campaign to upgrade the city of Espoo into a utopian metropolis, Jaana spends all her energy trying to bring through a legislative package to reduce poverty, which is resisted by her 
conservative party comrades. The central conflict of the play is a dispute between Jaana and Rami on his concept of the so-called Performance Economy. In his business seminars Rami argues that an understanding of performance techniques is necessary for a successful private and working life. Jaana criticizes his concept for being authoritarian and undemocratic as it allows successful performers to push through political or economic projects against the majority of the people. In his play Jokela shows how Rami uses his knowledge of the functioning of a good performance to achieve economic success, while Jaana faces difficulties getting her programme through the partys committees. Another character, the fictitious theatre researcher Hanna Krohn, has the role of being a critical observer of the conflict between the two and reflects on the manipulative power of performance techniques in seminar-like presentations that recall Brecht's L ehrstücke (in English: learning plays). ${ }^{12}$

Jokela's play shares characteristics with Brecht's epic theatre in two areas. First, both Jokela and Brecht pursue the same objective to put the audience in the position of a critical observer both by revealing performance practices and by creating a distance between the audience and the action on stage through the verfremdungseffekt. ${ }^{13}$ Second, they both take a dialectic stance on society to stress societal contradictions and to show the variability of society. ${ }^{14}$

\section{THE USE OF THE VERFREMDUNGSEFFEKT IN ESITYSTALOUS}

In the production of his play, Jokela makes use of the verfremdungseffekt in various ways, which are created by the use of video footage and are probably influenced by the works of Frank Castorf or his followers. Video footage, both live and pre-produced, is applied almost consistently in the performance. It is used, for example, for close-ups of the actors, for showing scenes that take place in a space not visible for the audience, and for scenes which are played in front of blue screens and in which chroma keying is applied on the live video footage.

The use of the video footage results in various forms of the verfremdungseffekt. First, it creates a mixture of forms of representation, video and theatre, which differ a lot from each other, for example, in terms of the distance they create to the spectator. By mixing the two forms the audiences attention is drawn to the differences between them, and its awareness of the fictitious character of the events on stage is raised. Sometimes the actors can even be seen twice, on the screen and on stage, which makes the distancing effect created by the video footage even stronger. Additionally, Jokela plays around with this effect: In one scene, for example, he shows on one screen, an intimate and film-like naturalistic moment filmed by a camera in the dressing room behind the stage while showing, on another screen, a projection of the play text of the same scene. Here a most clear disillusion is created by disclosing the fictitious character of the events on stage.

Camera operators and their equipment are also visible in the scenes in which live camera footage is used on stage. In the scenes in which chroma keying is applied on live video footage, the actors step in front of a blue screen and the audience can observe how the cinematic effect is created. At the same time the audience can see the result of the effect on the screen and the way it is created on stage. This way the attention of the audience is drawn to the realisation of the theatrical or cinematic effect and the spectators become aware of the manipulative possibilities of theatre. In addition, a distancing effect is evoked by the images created via chroma keying as they make the characters appear on images that remind the audience of movies from the fifties, which do not fit into the setting of the rest of the play.

Another kind of verfremdungseffekt is created by the appearances of the fictitious theatre researcher Hanna Krohn, who enters the stage several times during the play to give academic lectures. Hanna Krohn's lectures are supported by video footage as well. In her presentations, Hanna shows the audience sequences of a fictitious TV documentary about her life and critically comments on its attempt to dramatize her fate and create a story that will be of interest to the 
audience. Commenting on the video sequences, Hanna critically approaches the potentialities of performances, the plot of the play and the role of the playwright, therefore also creating a critical distance to the action and the topic of the play. ${ }^{15}$

While the use of video footage and the way Jokela inserts critical comments in the performance are clearly in the Brechtian tradition, the acting style applied in his production points in another direction. Besides short moments in which the actors break character and perform songs here again a reference to Brecht is obvious the acting, the language as well as the make-up and the costumes used in the performance are very naturalistic. The unity of actor and role is not disturbed, which makes it possible for the audience to identify with the characters on stage to a certain degree. ${ }^{16}$ Here, a contrast to Brecht can be seen, who demanded a distance between actor and role ${ }^{17}$ and also to Castorf, who realises this distance in his performances by building up a tension between the actors and the characters they present on stage. ${ }^{18}$

\section{DIALECTICS IN ESITYSTALOUS}

Not only does Jokela adapt parts of Brecht's concept of alienation in Esitystalous, but also the second pillar of Brecht's epic theatre, a dialectic description of societal reality, is very prominent in the play. Because of its dialectically shaped character, Esitystalous can be read and seen as a parable in terms of Brecht as it suggests dialectics as a tool to understand societal processes and relations. In Esitystalous, Jokela teaches dialectic thinking by highlighting the contrariness of social conditions. Hanna's seminars communicate a dialectic approach to both reality and fiction to the audience, and characters such as Jaana and Rami embody specific types of societal beings, for example, the young idealistic leftist politician and the middle-aged successful neoliberal manager, which can be transferred by the audience to societal patterns known to them. Three times in the play Rami and Jaana are even given the possibility to argue out their different opinions in debates on stage. The audience is confronted with verbal disputes that go into detail and is given the

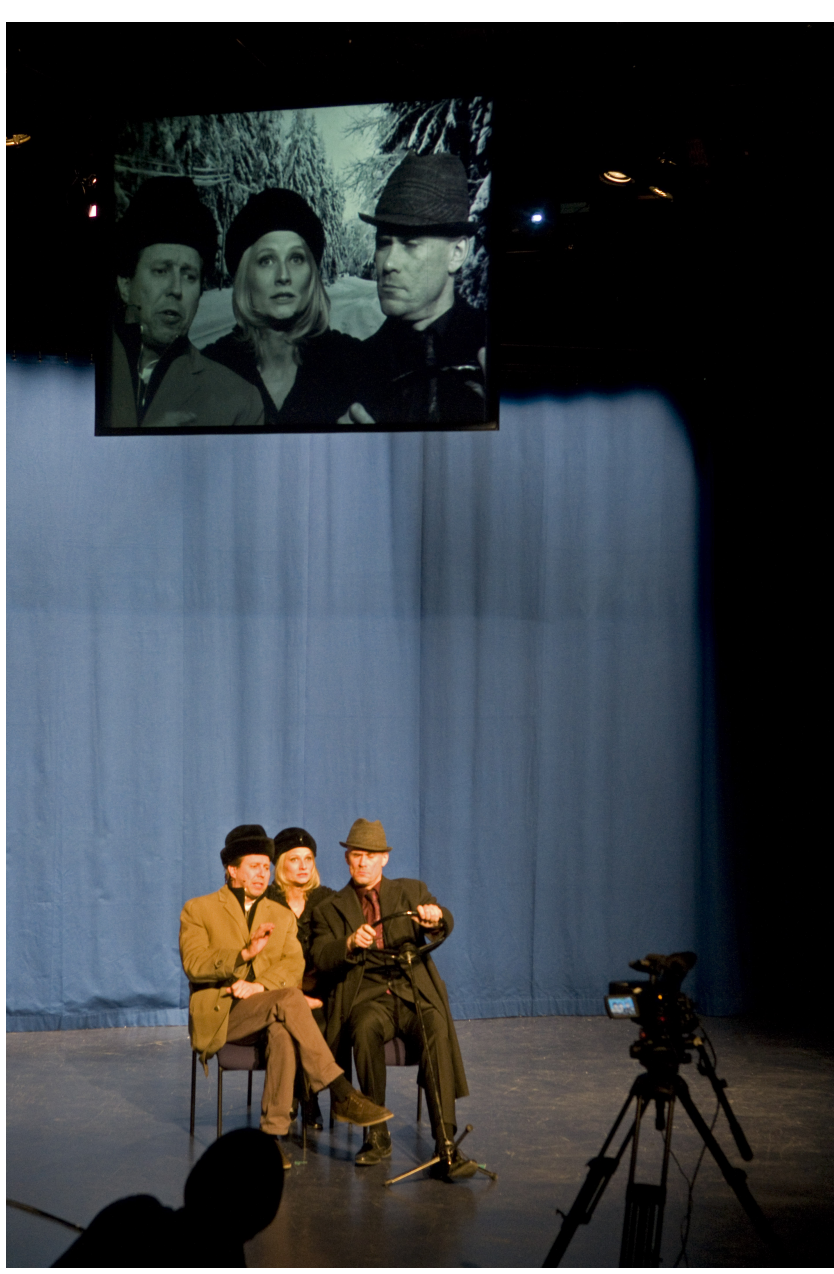

Chroma keying in the performance of $E$ sitystalous at the E spoo C ity Theatre. On stage, M artti Suosalo, V era Kiiskinen and Tommi Korpela. Photo Teppo Järvinen.

chance to listen to the arguments of both sides. In these debates, Jokela successfully manages to show positive and negative sides of both characters. Esitystalous is, therefore, never moralistic or tries to convey a message, but suggests that the audience take a critical stance towards the events and disputes shown on stage just as Brecht demanded. ${ }^{19}$

At the end of the play, Jaana, whose proposals were not heard by the party committees, hijacks the stage at a party convention to finally present her plans to fight poverty to the public. This dramatic final scene of the play could appear as a call for political intervention, but here again Jokela sticks to his dialectic approach and closes the scene with a choir including all the actors who sing John Lennons both pathetic and ironic song, Working Class $\mathrm{H}$ ero. This final scene of the 
performance brings to mind the final choir in Brecht's The Good Person of Szechwan that asks the audience to find a better ending for the story. ${ }^{20}$ Jokela's dialectic approach can be traced back to the one Brecht describes in his writings, but differs from Castorf's approach, which is influenced by Heiner Müller and postdramatic concepts. Jokela grapples with todays problems by telling a story that takes place in the here and now, pointing out societal contradictions as demanded by Brecht. ${ }^{21}$ Castorf, on the other hand, takes old texts, often novels, as the basis of his plays, and looks for issues in these texts that he still finds relevant today and which evoke associations. ${ }^{22}$ Castorf applies a postdramatic collage technique and takes the texts apart, puts new bits in and has been, therefore, often called a text destroyer. ${ }^{23}$ While Jokela wants to make the audience aware of the use of performance techniques and to think about societal developments, he still sticks to the conventions of the theatre. Castorf meanwhile, not only looks in a dialectic way at both theatre and society, but destroys the conventions of the theatre by disturbing the unity of actor and role, the linear story-telling and the role of the audience. 24

\section{A NEW APPROACH TO POLITICAL THEATRE}

To conclude, Castorf's and Jokela's approach share similar Brechtian ideas and techniques such as the concept of alienation, a dialectic view on society or the use of video footage, but at the same time their approaches differ in the way they deal with the traditions of the theatre and the expectations of the audience. Todays political theatre in Germany is still very much influenced by postdramatic concepts and corresponds, for the most part, with the critique Hans-Thies Lehmann expressed on political theatre in his monographs Postdramatisches Theater (in English:
Postdramatic Theatre, 1999) and Das Politische Schreiben (in English: Writing the Political, 2002). In these writings, Lehmann rejects the representation of political conflicts on stage and even rejects the notion of discussing political conflicts at all in the theatre. In his opinion, only the how of the rendering of a play could generate political substance but not the content of it. ${ }^{25}$ According to Lehmann, the political of the theatre must not be conceived as a reproduction of the political but as its interruption. ${ }^{26}$

Lehmann's thesis is problematic as it favours, from the start, postdramatic forms over dramatic forms of theatre and does, therefore, not reflect todays reality of political theatre either in Germany or in Finland. New dramatists nowadays express their political criticism both in form and content, which are hardly separable in terms of their effect on the audience. Jokela combines the Brechtian verfremdungseffekt with the conventions of the Finnish theatre and creates a theatre that assumes the variability of social conditions and suggests a dialectic view on society without being moralistic or dogmatic. Jokela's theatre is both critical and entertaining, and is therefore accessible for a large public. As new drama is so popular and audience numbers have increased continuously in the last few years in Finland, this new form of political theatre seems to be highly acceptable to theatre audiences. Besides the desire to be entertained, one reason to go to the theatre today actually seems to be to get involved in a political discourse. For the new generation of theatre makers, Brecht's methods signify the starting point of a new political theatre that critically and openly discusses political issues, and provides an opportunity for the audience to take part in societal discourse and, therefore, in the life of society. ${ }^{27}$ 


\section{NOTES AND REFERENCES}

1. Niklas Füllner, Theater ist eine V olk ssauna. Politisches G egenwartstheater aus Finnland in der Tradition von Bertolt Brecht, epodium Verlag, München 2014, pp. 74-89.

2. 2010 Teatteritilastot F innish T heatre Statistics, TINFO Finnish Theatre Information Centre, Helsinki 2011, p. 8.

3. W er spielte was? W erkstatistik 2009/2010, Deutscher Bühnenverein, Mykenae Verlag, Köln 2011, p. 40-44.

4. Hanna Helavuori, "Texts and Bodies on Stage Contemporary Finnish Theatre," Stage: H elsinki T heatre Festival Finnish Case 2011, TINFO Theatre Info Finland, Helsinki 2011, p. 24.

5. Füllner, op. cit., pp. 97-112.

6. Ibid., pp. 112-117.

7. Ibid., p. 371.

8. Steve Earnest, "Frank Castorf at the Volksbühne am Rosa Luxembourg Platz: Alienation Techniques and the Use of Mediated Material on the Live Stage," Theatre Symposium, Annual, Vol.19, 2011, p. 41.

9. Füllner, op. cit., p. 371.

10. Ibid., pp. 370-371.

11. The analysis of Juha Jokela's E sitystalous is based on a visit to its guest performance at Tampereen Teatterik esä in Tampere-talo on 6 August 2010 as well as on a video recording of the performance at Espoon

Kaupunginteatteri on 11 May 2010, and on the unpublished English translation of the play by Kristian London: Juha Jokela, Performanœ E œnomy,

Näytelmäkulma Nordic Drama Corner Oy, Helsinki 2010.

12. Füllner, op. cit., pp. 314-317.

13. Bertolt Brecht, "Über experimentelles Theater," Bertolt Brecht, B ertolt Brecht W erke, G rosse k ommentierte B erliner und Frankfurter A usgabe, Band 22, Schriften 2 Schriften 1933-1942 Teil 1, Werner Hecht, Jan Knopf, Werner Mittenzwei and Klaus-Detlef Müller, Aufbau-Verlag Berlin and Weimar, Suhrkamp Verlag, Frankfurt am Main 1993, pp. 554-555.

14. Bertolt Brecht, [Vom epischen zum dialektischen
Theater], B ertolt Brecht, Bertolt Brecht W erke - G rosse k ommentierte Berliner und Frank furter A usgabe, Band 23, Schriften 3 - Schriften 1942-1956, Werner Hecht, Jan Knopf, Werner Mittenzwei und Klaus-Detlef Müller, Aufbau-Verlag Berlin and Weimar, Suhrkamp Verlag, Frankfurt am Main 1993, p. 301.

15. Füllner, op. cit., p. 319-329.

16. Ibid., pp. 344-346.

17. Bertolt Brecht, "Die Strassenszene. Grundmodell einer Szene des epischen Theaters," Bertolt Brecht, Bertolt Brecht W erke - G rosse kommentierte Berliner und Frank furter A usgabe, Band 22, Schriften 2 Schriften 1933-1942 Teil 1, Werner Hecht, Jan Knopf, Werner Mittenzwei und Klaus-Detlef Müller, Aufbau-Verlag Berlin and Weimar, Suhrkamp Verlag, Frankfurt am Main 1993, p. 376.

18. Erika Fischer-Lichte, "Frank Castorf's Spiele mit dem Theater: Wie das Neue in die Welt kommt", Forum M odernes Theater, Gunter Narr Verlag, Tübingen 2006, pp.5-23, p. 13.

19. Ibid., pp. 329-333.

20. Bertolt Brecht, D er gute M ensch von Sezuan, in: Bertolt Brecht, Bertolt Brecht W erke - $G$ rosse kommentierte Berliner und Frankfurter A usgabe, Band 6, Stücke 6, Werner Hecht, Jan Knopf, Werner Mittenzwei und Klaus-Detlef Müller, Aufbau-Verlag Berlin and Weimar, Suhrkamp Verlag, Frankfurt am Main 1989, pp.. 278-279.

21. Bertolt Brecht, [Kleines Organon], in: Bertolt Brecht, Bertolt Brecht W erke - G rosse kommentierte Berliner und Frank furter A usgabe, Band 23, Schriften 3 Schriften 1942-1956, p. 74.

22. C. Bernd Sucher, D as Theater der achtziger und neunziger Jahre, Fischer Taschenbuch Verlag, Frankfurt am Main 1995, p. 187

23. Earnest, op. cit., p. 42.

24. Fischer-Lichte, op.cit., p. 13.

25. Hans-Thies Lehmann, D as Politische Schreiben, Theater der Zeit, Berlin 2002, p. 21.

26. Ibid., p. 17. Author's translation.

27. See Füllner, op. cit., pp. 354-355.

Niklas Füllner studied Theatre Research and English Literature and Culture at the universities of Bochum, Bayreuth, and Helsinki, and finished his $\mathrm{PhD}$ at the Institute of Theatre Studies at Ruhr University Bochum, Germany, in 2014 with his dissertation entitled Theater ist eine Volkssauna. Politisches Gegenwartstheater aus Finnland in der Tradition von Bertolt Brecht. Currently, he is a lecturer at the Centre for Fine Arts of Ruhr University Bochum and puppeteer for the Düsseldorf-based performance group half past selber schuld. 